American University Washington College of Law Digital Commons @ American University Washington College of Law

Articles in Law Reviews \& Other Academic Journals

Scholarship \& Research

1993

Constructions of the Client within Legal Education

Ann Shalleck

Follow this and additional works at: https://digitalcommons.wcl.american.edu/facsch_lawrev

Part of the Education Law Commons, and the Legal Education Commons 


\section{Constructions of the Client Within Legal Education}

\section{Ann Shalleck*}

Within legal education, clients are paradoxical figures. Although they are mostly absent from classroom discussions, devoid of lives or places in the world, they can suddenly emerge, as if from nowhere, with clear identities and characteristics, to fill critical gaps in the classroom discussion. The clients who make these sudden appearances are seemingly unproblematic figures. Professors and students easily presume agreement as to who they are and what they want. Within the legal system, all seek wealth and freedom. The clients who are missing from legal education are clients with particular identities who are situated in distinctive ways within the social world, facing often critical choices about their participation in the legal world. Defying the presumptions of the professor and students, these absent clients may have not only their own understanding of what they want from involvement in the legal system, but also their own visions of the legal order and social and political life. They are, however, banished from the classroom, forced out by the presumptive clients who serve as an invisible but necessary pillar of the legal discourse of the classroom, made to supply in unobtrusive and unproblematic form the ends that the law and the legal system are working to achieve. ${ }^{1}$ By occupying the space reserved for the client within legal thought, these constructed clients of legal education permit the familiar classroom dialogues to proceed.

For the most part, no one notices these constructed clients. Law professors facilitate discussions about the law, its principles and rules, its structure and contradictions, its possibilities and limitations. They also talk about legal institutions, their capacities and defects, their origins and development. And law classes increasingly focus on the long neglected subject of the actual day-to-day practice of lawyers, their activities and distinctive ways of think-

* Ann Shalleck, All rights reserved. Professor of Law, American University. James Boyle, Robert Dinerstein, and Elliott Milstein gave valuable comments on an earlier draft. Peter Jaszi and James May helped me clarify my thoughts. Suzanne Schwartz and Laura Middleton provided able research assistance.

1. See Pierre Schlag, The Problem of the Subject, 69 Tex. L. REv. 1627 (1991), for a general discussion of how legal subjects, often seemingly missing participants, are actually used within contemporary legal discourse to prefigure the ends of that discourse. These subjects, through their prefigurations, the characteristics implicitly ascribed to them, provide the motivations or generate the action within that discourse. Although Schlag does not address clients specifically, his analysis helps to reveal the particular ways that constructions of the client as legal subject are both necessary to and invisible within contemporary legal thought. See also James Boyle, Is Subjectivity Possible? The Post-Modern Subject in Legal Theory, 62 U. CoLo. L. REv. 489, 506-23 (1991). 
ing, their ethical dilemmas and roles in society, their skills and professional relationships. Whether these discussions are doctrinal, theoretical, or practical, the professors often assume yet barely mention these cardboard clients, thereby excluding the very people whose lives and work, whose problems and desires, bring them into contact with the legal system. ${ }^{2}$

This exclusion occurs unconsciously in many different ways and in many different contexts. It is so commonplace that students are not even troubled by it. While a class without rules or policies, courts or lawyers, would make most students nervous, maybe even angry, the same students would not even notice a class without clients. The absence of clients from inquiry does not, of course, make them disappear; rather, presumptive clients unobtrusively inhabit a realm where no one challenges the prevailing assumptions about who they are, what they want, and why they are participants in the legal system. Real clients are nowhere to be found.

This essay enters the realm of the client. It discusses how and why clients are consigned to this largely invisible but indispensable realm. It explores the assumptions that we have made about them. These assumptions, rather than telling us anything about real clients and what they want from the legal system, shed light on the nature of legal discourse about law, the legal profession, and legal institutions.

In the first part of this essay, I examine several ways that legal education constructs clients. I discuss two routine practices used in law schools to exclude actual clients from formal discussion and to replace them with clients with predetermined characteristics: (1) the treatment of facts, and (2) the framing of legal arguments. Both methods powerfully illustrate how we construct clients within our routine educational practices without anyone being aware of what is happening. These routine practices permit us to transform clients by stripping away their defining characteristics and simultaneously giving them new identities that situate the constructed clients firmly in the existing terminology of legal discourse. In addition, I examine the part of the curriculum where clients are an explicit part of the educational agenda: legal ethics. Courses in legal ethics frequently emphasize the relationship between lawyer and client. I identify how the classroom treatment of legal ethics replicates and reinforces the construction of the client carried out in the rest of legal education.

In the second part of the essay, I examine the efforts of legal scholars and commentators during the last two decades to reclaim and reshape the realm of the client and thereby to challenge prevailing forms of legal thought that

2. The absence of clients from legal education has been noted by many since the time of the legal realists. See, e.g., Jerome Frank, A Plea for Lawyer-Schools, 56 YALE L.J. 1303, 1303-04, 1318 (1947); Howard Lesnick, Infinity in a Grain of Sand: The World of Law and Lawyering as Portrayed in the Clinical Teaching Implicit in the Law School Curriculum, 37 UCLA L. REv. 1157, 1179 (1990); Austin Sarat, Lawyers and Clients: Putting Professional Service on the Agenda of Legal Education, 41 J. Legal Educ. 43, $43-44$ (1991); cf. Thomas L. Shaffer \& Robert S. Redmount, Legal Education: The Classroom Experience, 52 NotRe DAME L. Rev. 190 (1976) (advocating greater attention to the lawyer-client relationship within legal education). 
dominate the discourse of legal education. I trace these efforts from the creation of live-client clinics, through the development of "client-centered lawyering," to the emergence of a "theoretics of practice." Finally, I examine the significance of the construction of clients to attempts to reform legal education by incorporating ideas of civic virtue.

\section{The Construction of Clients: Excluston AND INFusion}

\section{A. Routine Practices}

One way to discover how the typical law school classroom constructs a client is to investigate the routine practices of legal education and the assumptions about clients that are embedded within them. Two of these routine practices serve as examples: the statement of facts and legal argumentation.

\section{The statement of facts.}

I shall begin with a practice repeated day after day, in classroom after classroom. In law schools around the country, professors ask students to state the "facts of a case." Reiterating the account of the facts contained in the appellate opinion, the student begins to tell "what happened" in the case. Neither the professor nor the student shows any discomfort with the question or the answer. Once the facts are laid out, the professor and student proceed to the important business of analyzing the "legal" issues-whether regarding policy, doctrine, or theory - that these facts present. In an effort to guide students toward discovering the nuances, complexities, or contradictions in a case, the professor may alter or rearrange "the facts" in a series of hypotheticals. ${ }^{3}$

Through this simple exercise two important steps in the construction of the client occur. The first step strips the clients of individual identity, wiping out any of their unique understandings of, or experiences in, the world. This process severs clients from the social world that gave rise to their case. The second step gives the denuded clients new identities and understandings derived from the court's interpretation of the legal framework of the case. Removed from the social world, clients are placed in a world defined by the legal categories and concepts used by the court.

The first step—removing clients' actual experiences in the social worldhas two related aspects. First, in the exchange between professor and student, the class faithfully adopts the appellate court's version of the facts as an unproblematic account of what happened in the world. There is no ac-

3. Despite scholarly criticism of the legal treatment of facts within legal education going back to the legal realists, particularly the fact skeptics among them, attitudes toward and practices regarding facts have remained highly resistant to change. See, e.g., Frank, supra note 2, at 1306-08, 1311. Elsewhere I have discussed the importance of questioning and destabilizing appellate courts' accounts of the facts of cases. See Ann C. Shalleck, Feminist Legal Theory and the Reading of O'Brien v. Cunard, 57 Mo. L. REv. 371 (1992); see also Gerald P. López, Training Future Lawyers to Work with the Politically and Socially Subordinated: Anti-Generic Legal Education, 91 W. VA. L. REv. 305, 338-39 (1988-1989). 
knowledgment that almost certainly the actual experiences of each of the parties differ from the facts recorded by the appellate court. Likewise, there is no acknowledgment of the multiple reinterpretations of each client's story that occurred during the different stages of the legal process. That process generated numerous interpretations of each client's experiences: the story told to the lawyer (or, more accurately, the story as it evolved during the ongoing interactions within the lawyer-client relationship); the story told through pleadings and other court documents; the story told in pretrial litigation, through interrogatories, depositions, affidavits; the story told at trial, through witnesses and documents; the story told by the jury's or judge's findings of fact; and the story told by the resulting briefs and appellate record. Only at the end of this lengthy legal process is there an appellate opinion. ${ }^{4}$ The professor and student treat these multiple layers of reinterpretation as if they never occurred..$^{5}$

The second problem with the professor-student colloquy is that the appellate court's statement of the facts is accepted as authoritative. The professor and the student focus on what the appellate court says happened. This is true even in those extreme cases where there are strong indications that the court was wrong in some significant respect, let alone in routine cases where the problems with the court's account are more subtle and complex. The professor-student dialogue reveals a tacit and willing acceptance of the "certainty" produced by the court's statement of the facts, a result that is in direct contradiction to the open acceptance of ambiguity that characterizes evaluation of the same court's statements about the law. The definition of the social world and clients' positions within it is not open for inquiry in the typical classroom dialogue. Professor and student accept the facts as offered, defined in the text of the court's opinion, and move quickly to analyzing and critiquing the possible and indeterminate legal solutions available in this particular situation. These classroom dynamics suggest that it is not the business of legal education to probe, to analyze, or to criticize why the world appears as it does in the court's opinion, much less to investigate how clients' actual experiences might be different. ${ }^{6}$

By making the court's statement of the facts appear unproblematic and authoritative, this routine practice destroys any real opportunity to inquire into clients' particular circumstances or their social world. The first step in the construction of the client has been quickly and efficiently accomplished. Clients are stripped of their identities, and their experiences are stripped of real meaning-save any attributed by the court.

Which bring us to the second step in the construction of the client pro-

4. See Frank, supra note 2, at 1306-08, 1315.

5. Although at some level both teacher and student are probably aware of these layers-especially the partiality of the appellate court's account of the facts-this awareness is put aside to engage in the stylized dialogue so commonplace in legal education.

6. Again, at some level, teacher and student probably both know that courts may be unreliable interpreters of the clients' social world, and that the clients' actual social world may look very different from the court's statement of facts, but this knowledge is ignored during the course of the dialogue. See Lesnick, supra note 2, at 1172. 
duced by this classroom exercise. At the same moment that clients are disconnected from their social world, the court attributes its own meaning to clients' experiences. That meaning derives from the court's understanding and interpretation of the law. Only the clients' characteristics and experiences that have relevance to the law as presented by the court are chosen as the facts of the case.

There are two consequences to the court's choice of "relevant" facts. First, it appears natural for law to give meaning to a client's life and social world. Second, the factors or forces that shape this meaning are hidden from view. The court does not explain why it views clients and their social world in one way or another. Neither does the classroom dialogue explore the possible sources of the court's attributed meaning and the process by which the court establishes it. The only choices that the class subjects to scrutiny are the choices about the law. The court does not address and the classroom discussion further disguises the relationship of the court's choices about the law to its presentation of clients and their social world.

\section{Legal argumentation.}

Another example of how we construct the client can be seen in a second routine practice of legal education: the mystified teaching of legal argumentation. Although the explicit agenda for the class may be the teaching of substantive law, law professors frequently use the classroom to teach standard forms of legal argumentation. The professor may ask, "If you represented the plaintiff, what would you argue in support of this rule?"; "What's the counterargument for the defendant?"; and "How would the plaintiff respond?" This exchange proceeds back and forth, over and over, until students engage in a number of common forms of legal argument. The students address the applicability of the rule to the particular situation, the significance of the policies behind the rules, the competence of the institutions making or interpreting the rules, competing needs for predictability versus flexibility, and the value of formal realizability compared to discretionary, case-by-case decisionmaking. These and other standard arguments are practiced over and over, as students are taught to master the proper methods of legal discourse and persuasion. This is the mythical "thinking like a lawyer" that law school strives to produce. ${ }^{7}$

This second exercise, more complicated than the first, accomplishes a related result. The unique motivations and desires, the visions and values, of the actual clients seem irrelevant to the nature of the arguments offered to support a particular result. There are three aspects of this phenomenon. First, although the plaintiff and the defendant, the clients, are nominally present in the discussion, they appear as cardboard figures. The arguments

7. For a discussion of an attempt to demystify the teaching of legal argumentation, see James Boyle, The Anatomy of a Torts Class, 34 AM. U. L. REv. 1003, 1015-23, app. at 1051-63 (1985); see also Pierre Schlag \& DAvid Skover, TACTics of Legal Reasoning (1986) (providing a taxonomy of standard legal arguments). 
the students make, arrived at entirely without reference to the clients, are determined by and confined within structures of argumentation that reflect the available and acceptable categories of legal analysis. At no time in this orchestrated exchange do the professor and students view the clients as participants in the ethical or strategic decisions about what arguments could or should be made. Because the class excludes clients' experiences from the discussion, there is no real possibility that students can frame arguments in terms of those experiences. Moreover, the professor and students do not discuss what meaning the available legal arguments might have to the clients. Nor is there any sense that, in deciding how to choose and frame legal arguments, the attorney might need to confer with the clients to understand better their goals in a case, their vision about justice or fairness, or their perception about the role of law and the legal system.

Second, the arguments seem to have an independent existence within the legal world, entirely separate from the clients and their social world. The class need not even make meaningful reference to the client-the person on whose behalf the argument is made. The arguments appear wholly contained within the parameters of the professional discourse about the law, and are found and used solely within that sphere. The terms and meaning of the legal discourse entirely determine whether the professor and students consider the arguments good or bad.

Just as the first exercise stripped clients of their identities and experiences, this one strips them of their desire and commitment. The class entirely pares away the clients' reasons for being in the legal system, their beliefs about law and legal institutions, their aspirations for what could be achieved, and their understandings of how the law relates to their sense of self and their communities. When teaching legal argumentation, the professor disconnects these aspects of clients' lives from choices about the content and form of legal arguments. Since the arguments seem to belong only in the legal realm, they are primarily the responsibility of legal professionals.

Third, at the same moment that the clients lose their own values and motivations, the class, in performing the exercise in argumentation, makes assumptions about what the clients' values and motivations might be. Because there is no reference in the classroom discussion to what clients might actually want or value, the class must make some attribution for the purpose of framing arguments. The students assume that an argument for the plaintiff is any argument to win. Further, they reflexively define "winning" as avoiding the greatest cost or accumulating the greatest benefit. Clients simply want to maximize monetary gains (or minimize losses) and achieve the greatest possible degree of freedom and autonomy in their actions. Thus, clients become consummate cost benefit calculators, and the terms of the cost benefit analysis are accepted as relatively straightforward. As the students rehearse legal arguments on behalf of clients, these assumptions need no formal pronouncement. The arguments can be stated without reference to clients, of course, only because the professor and students already have assumed the clients' needs and desires. 
In these two routine practices of legal education, then, we begin to see a vision of clients as legal subjects. While the clients are situated outside of the legal realm, their identities are created and their experiences given meaning only within the existing terms of legal discourse. The law decides which of the client's characteristics will have meaning in a case and defines the nature of the experience that brings the case to court. Finally, the law creates the motivations and values that animate the clients' interests in the case. ${ }^{8}$ This construction of clients can also be seen elsewhere within legal education, for example, when clients meet the lawyer in a professional responsibility course.

\section{B. Professional Responsibility}

Because clients are an explicit part of the curriculum of most courses in professional responsibility, they appear with greater frequency and are accorded greater attention than in much of the rest of legal education. They are also often visible outside of appellate opinions and are thus not viewed as constrained by our legal culture's powerful practices and traditions regarding the analysis of adjudication. In addition, they are present in this course as participants in a relationship with a lawyer, and, therefore, not cut off from all social context. Despite these differences in the presentation of clients in professional responsibility courses, however, this part of the curriculum continues, rather than departs from, the construction of the client carried out in standard classroom practices.

There are two notable characteristics of the clients who appear with frequency in professional responsibility courses. First, they are almost always people who want wealth or freedom and have violated or are willing to violate commonly accepted norms of conduct to achieve these goals. They want to lie or cheat or harm others in pursuit of their objectives. They are the constructed clients of the standard classroom gone awry-they want the right things, but they have chosen inappropriate means. In the professional responsibility classroom discussion, these clients remain cardboard figures, supplying only bare motivations-to obtain freedom although guilty of a crime or to get rich through defrauding others-that present complex and nuanced questions for the lawyer. The classroom dialogue focuses primarily on how to deal with these motivations within the framework of legal discourse-the rules that govern advocacy behavior, the ideology underlying those rules, the conflicting values that lawyers must resolve in making decisions, and the scope of discretion available for lawyers' decisionmaking.

8. In his examination of subjectivity in classical, realist, and contemporary legal and political thought, James Boyle has identified the characteristics of the constructed subjects of legal thought that are quite similar to those found in the clients constructed through the routine practices of legal education. For example, the motivations of the clients of the classroom are quite similar to John Rawls' subjects, who act according to rational self-interest, meaning love of material wealth and freedom of action. Similarly, clients, whose characteristics are defined by criteria of relevance applied by the judge, are given identities in the same way as the legal subjects of realist thought, who obtain prominent features depending upon the policy goals of legal decisionmakers. Boyle, supra note 1, at 509, 511-16. 
The predominance of these inappropriate wealth and freedom maximizers in the professional responsibility course is a testament to the important role that constructed clients play in providing motivations for the legal system. At the margins, their motivations must be constrained, or at least seem to be constrained, and these bad clients provide the opportunity for asserting those constraints within legal discourse. The ambiguities and complexities of the client's actual situation, the multiplicity and confusion of goals that commonly characterize client behavior, even behavior that violates common norms of conduct, the lawyer's ability to know and understand the client, and the social context of the client's harms are peripheral concerns. The motivation and the constraint are central.

Second, the clients who appear in professional responsibility courses, even those clients who do not fit the dominant portrait described above, are seen as having subjective, determinate, articulated interests constituted prior to their interactions with a lawyer. ${ }^{9}$ These clients come to lawyers already knowing what they want. The job of the lawyer is to discover what these clients want and, having identified their desires, to offer choices about how to achieve their legitimate goals within the legal system. As with the deviant clients, these regular, run-of-the-mill clients offer their fully formed motivations to the course.

Several aspects of these motivations are important in the construction of the client. First, the professional responsibility course places the process of defining interests outside of the lawyer-client relationship. Motivations are possessed by clients and discovered by lawyers, not created or shaped through interaction with the lawyer. Second, the course presents the process of discovering the clients' motivations as relatively straightforward and transparent. The class takes clients' motivations as given, and discussion in the course focuses on the problems that arise after the motivations are established, as, for example, in the areas of conflict of interest or group representation. Third, the course treats the content of the motivations as formally neutral, so long as the client's goals are within accepted social norms. Clients are the sole judge of their interests. Lawyers just further those interests in legitimate ways.

This view of client motivations is important to legal discourse in at least two ways. First, although treating these motivations as seemingly empty boxes filled up only by the client, the legal system actually makes numerous assumptions about client interests. Whenever client interests are in doubt or are deemed too difficult to discover, they can be tacitly presumed. ${ }^{10}$ Those presumptions appear least problematic when they contain preferences for motivations for wealth or freedom. ${ }^{11}$ Second, the legal system treats the

9. See William H. Simon, Visions of Practice in Legal Thought, 36 STAN. L. REv. 469, 469-70 (1984); see also Warren Lehman, The Pursuit of a Client's Interest, 77 Mich. L. REv. 1078 (1979).

10. See Simon, supra note 9, at 477-82 (discussing how presumptions about client interests have been used within the legal system).

11. See, eg., Albert W. Alschuler, The Defense Attorney's Role in Plea Bargaining, 34 Yale L.J. 1179, 1205-06 (1982); Lehman, supra note 9, at 1087-88; Stephen C. Yeazell, From Group Liti- 
content, the source, and the meaning of these motivations as outside the realm of legal discourse. Although these motivations supply the ends for the legal system, the forces that shape the motivations need never be addressed as legal issues. The social context within which the client's motivations arise is not a topic of discussion.

As in the regular classroom, the constructed clients of the professional responsibility course force out the real clients. Students do not see the worlds that the clients come from, the institutions that shape the clients' lives, and the choices, or the conflicts, confusion, and uncertainty that some bring with them to the lawyer's office. Students have no sense of how hard it often is to identify what a client wants, nor do they develop any insight into how they themselves can participate in shaping clients' understanding of the client's goals. Students do not learn how to attend to the ways power operates within their client relationships, nor are they taught the role it can play in the definition of client interests.

\section{Recovering the Client}

\section{A. Representing Clients Within Legal Education}

The process of recovering real clients from the netherworld to which they have been banished, and thereby challenging the constructed clients within legal education, began in earnest twenty-five years ago with the widespread creation of "live-client" clinics within law schools.12 The creation of these clinics was part of a larger critique of law and legal education emerging at that time. ${ }^{13}$ Although there were many aspects of these early educational programs and many ways in which they sought to challenge the existing practices of legal education, I want to focus on the centrality of the client.

Given the pervasiveness of the mechanisms that keep actual clients largely invisible within legal education, making clients the centerpiece, one of the essential defining features of this self-consciously transformative educational experience, was of enormous importance. Clinics created a powerful opportunity to challenge the construction of clients in legal education. By actually representing real clients with real legal problems, students could obtain alternative understandings of clients' lives and experiences. ${ }^{14}$ These

gation to Class Action-Part II: Interest, Class, and Representation, 27 UCLA L. REv. 1067, 1108-12 (1980).

12. The term was meant to distinguish educational experiences in which students provide legal services in the law school to actual people from (1) those in which students engage in role plays and simulations, and (2) those where students do not have clients, but work in outside legal institutions as interns.

13. See Jerold S. Auerbach, What Has the Teaching of Law to Do with Justice?, 53 N.Y.U. L. REv. 457, 470-71 (1978); Robert D. Dinerstein, Client-Centered Counseling: Reappraisal and Refinement, 32 ARIZ. L. REv. 501, 518-19 (1990); Panel Discussion, Clinical Legal Education: Reflections on the Past Fifteen Years and Aspirations for the Future, 36 CATH. U. L. REv. 337 (1987). This critique of the legal profession was itself a part of a larger social and political critique of many institutions of American society.

14. See, e.g., Gary Bellow, On Talking Tough to Each Other: Comments on Condlin, $33 \mathrm{~J}$. Legal Educ. 619, 621-22 (1983); López, supra note 3, at 322-23; Stephen Wizner \& Dennis Curtis, 
understandings could become more visible in legal education, challenging the view of clients commonly constructed in law school classrooms. Destabilizing the congealed vision of clients created the potential to undermine conceptions of the law, legal institutions, and lawyers dependent on the usual construction of clients. ${ }^{15}$

In challenging the constructed clients, two aspects of this early educational model are of particular significance. First, the model is based on a deeply contextualized understanding of who clients are and why they are significant. Students no longer see clients as abstract people with predetermined traits; rather, they see clients as unique individuals with particular characteristics situated within the social world. The clients' circumstances become important to the law students' understanding of not only a discrete case, but also the clients' relationship to the legal world.

For example, by seeing a client in relationship to the legal world, students can understand the decision about whom to represent not as incidental, or the result of externally fashioned student practice rules, but rather as a fundamental part of their work. The common practice within this educational model has been to represent people who are outsiders, poor or otherwise disadvantaged-people who are subordinated within the culture. Through this practice, students can understand clients whom they represent as people who mostly do not have access to the legal world-the world that is the exclusive focus of most of legal education. Even when the legal system is used to take coercive action against them-evicting them from their homes, taking away their children, repossessing their property-these people usually cannot find legal representation. The few lawyers who are available likely work in very difficult conditions, handling many clients with few resources. When students represent these clients as part of their legal education, the clients' basic characteristics, such as their restricted access to the legal world, act as starting points for developing knowledge about clients and their experiences, the work of lawyers, the legal world, and the social world.

Four examples of educational inquiries rooted in the clients' situation demonstrate the possibilities presented by this approach. First, students in the educational program can analyze who has access to the legal world, under what conditions, and why access is distributed in particular ways. Second, they can discuss the effects on legal institutions and legal concepts when groups of people have limited or no access to legal resources. They can address what fairness and due process mean to people who cannot even participate in the legal process; how formal equality looks to those who cannot get into court to claim unequal treatment; and how the experience of representing such people affects the students' evaluation of due process and

"Here's What We Do": Some Notes About Clinical Legal Education, 29 Clev. ST. L. REV. 673 (1980).

15. See Gary Bellow, On Teaching the Teachers: Some Preliminary Reflections on Clinical Education as Methodology, in CLINICAL EDUCATION FOR THE LAW STUDENT: LEGAL EDUCATION IN A SERVice SeTting 374, 377-78 (1973). 
equality. Third, students can investigate the meaning that the denial of access to the legal system can have in the clients' worlds. The class may discuss the consequences of the denial of access for the clients and their community, in terms of both the clients' material well being and their understanding of the legal system and the situation in which they live. The class may address what happens when only a fortunate few within a community have access to the legal system. ${ }^{16}$ Fourth, the students can explore what it means to be a lawyer for people who would otherwise be denied access to the legal system. The students experience the work involved in lawyering in a subordinated community and feel the emotions the work evokes. As they construct their lives as lawyers, they can compare such work to work for communities with ready, or partial, access to legal representation. ${ }^{17}$

The representation of clients within the law school can challenge the constructed client of legal education in a second way through the creation of an alternative educational dialogue that emphasizes seeing and hearing clients in their particularity and complexity. There is nothing inherent in the act of representing clients that creates a contextualized understanding of their lives. Not surprisingly, lawyers in their daily practice often replicate the construction of the client within legal education. Therefore, part of the impetus to create new educational models was the realization that even lawyers engaged in the representation of outsiders may recreate through their own practices their clients' exclusion from the legal world. ${ }^{18}$ Without a different kind of dialogue about clients, bringing clinics into law schools could reinforce rather than challenge the construction of the client. If students learned only dominant forms of practice, and not the critiques of nor the alternatives to those practices, they would learn in one more educational setting to substitute the constructed clients of legal discourse for the clients with whom they were actually working. Live-client clinics only present an opportunity, albeit a powerful one because of the immediacy and force of human relationships, to undermine the constructed client, as well as to develop and teach new methods for understanding and working with clients.

This opportunity has generated two different types of work. The first addresses the lawyer-client relationship. The second examines the educational context in which that relationship is understood and given meaning. The two types of work are deeply related for they are built on the premise

16. See, e.g., Gary Bellow \& Jeanne Kettleson, From Ethics to Politics: Confronting Scarcity and Fairmess in Public Interest Practice, 58 B.U. L. REv. 337 (1978).

17. Restricted access to the legal world is only one characteristic that identifies the clients represented within this educational experience. I use this example from live-client clinics to show how actual client characteristics provide an entry point not only for challenging the construction of the client, but also for developing a different understanding of the law, legal institutions, and lawyers. In many other ways, beginning with an understanding of the client's situation in the world, lawyers can expand their legal knowledge beyond the boundaries often set by the practices of legal education.

18. See Gary Bellow, Turning Solutions into Problems: The Legal Aid Experience, 34 NLADA BRIEFCASE 106 (1977); see also JeROLD S. AUERBACH, UNEQUAL JUSTICE: LAWYERS AND SOCIAI Change in Modern America 269-70 (1970); Comment, The New Public Interest Lawyers, 79 YALE L.J. 1069, 1119-37 (1970). 
that our educational practices are an integral part of how we come to understand clients and their lawyers, as well as the law and the legal system. For the purposes of this essay, I explore only the work about the lawyer-client relationship, ${ }^{19}$ the work that takes seriously the task of seeing and hearing clients. I begin with the concept of "client-centered" lawyering.

\section{B. Client-Centeredness}

The development of a "client-centered" approach to lawyering was another significant, though problematic, step in challenging the construction of clients within legal education. Most importantly, it explicitly and firmly places clients at the center of the lawyer's work in two fundamental ways. First, the theory requires the lawyer to listen to clients, to their accounts of events, to their emotions connected to those events, and to their understandings of those events. Part of the lawyer's work is to give clients time and space for self-definition. Neither the lawyer, the law, nor the legal system should substitute its own definition of the client and the client's experience. Second, the theory demands that clients have a meaningful role in making decisions about their cases; they should not merely ratify or reject the advice of their lawyers. Clients should be actively involved throughout the decisionmaking process, having a greatly increased scope and share of responsibility. To assert clients' meaningful participation, lawyers should explore and clarify their clients' desires and beliefs, not assume them. Although others have developed ideas of client-centeredness, ${ }^{20}$ the most influential statement of the approach was made by David Binder and Susan Price in 1977 in their widely used and cited book, Legal Interviewing and Counseling: A Client-Centered Approach.21 A second edition, entitled Lawyers as Counselors: A Client-Centered Approach, with an additional co-author, Paul Bergman, was published in 1991.22 These works provide a useful starting point

19. The second body of work concerns the creation and elaboration of educational models within clinical education that both foster a new understanding of clients and develop forms of legal practice based on that understanding. See, e.g., Anthony V. Alfieri, The Politics of Clinical Knowledge, 35 N.Y.L. ScH. L. REv. 7, 9-14 (1990); Susan Bryant \& Maria Arias, Case Study-A Battered Women's Rights Clinic: Designing a Clinical Program Which Encourages a Problem-Solving Vision of Lawyering that Empowers Clients and Community, 42 WASH. U. J. URB. \& CONTEMP. L. 207 (1992); López, supra note 3, at 360-86; Carrie Menkel-Meadow, The Legacy of Clinical Education: Theories About Lawyering, 29 CLEv. ST. L. REv. 555 (1980); Ann Shalleck, Clinical Contexts: Theory and Practice in Law and Supervision, 20 N.Y.U. REV. L. \& Soc. CHANGE (forthcoming 19931994); Wizner \& Curtis, supra note 14 , at 678,681 .

20. Thomas Shaffer was influential in the early development of the concept. See THomas L. ShafFER, LEGAL INTERVIEWING AND COUSELING IN A NUTSHELl 52-63, 128-30, 248-52, 273-76 (1976); see also ROBERT S. REDMOUNT \& ThOMAS L. SHAFFer, LEGAL INTERVIEWING AND Counseling (1980); Thomas L. Shaffer \& James R. ElkiNs, Legal INTERviewiNg and COUSEliNg IN A NuTSHell (2d ed. 1987).

21. David A. Binder \& Susan C. Price, Legal Interviewing and Counseling: A CiENT-CeNTERED APPROACH (1977).

22. David A. Binder, Paul Bergman \& Susan C. Price, Lawyers as Counselors: A Client-Centered Approach (1991). For the purposes of this essay, I treat the books as presenting a single theory. Although there are many changes in the second edition, none bear on the issues I raise. Therefore, in the text, I will refer to all three authors. 
for assessing the threat posed by client-centeredness to the constructed client.

The two ideas of listening to clients and including them as real participants in decisions have destabilized the constructed client of legal education. Unlike the constructed client of the law school classroom, Binder, Bergman, and Price clients have the capacity to define themselves and to explicate their own experiences. Moreover, they can draw on their own visions and motivations in choosing what happens in their cases. ${ }^{23}$ These qualities seemed attractive to many who wanted to foster a more deeply contextualized understanding of clients and to use that understanding as a way to reconceive the work of the lawyer, the law, and the legal system. ${ }^{24}$

In addition to a theory of client-centeredness, Binder, Bergman, and Price presented examples of the actual practice of client-centeredness. Rather than just claiming to put the client in the center, Binder, Bergman, and Price tried to figure out how to do it. Their work gave the concept concrete meaning in the actions of lawyers and law students. They wrote about such routine work as interviewing and counseling clients. By focusing on the law in operation, their work made clients more visible. ${ }^{25}$ Clients began to emerge from the shadows with a sense of self and their experiences somewhat intact. In addition, Binder, Bergman, and Price explicitly focused on how the lawyers' own actions affect client visibility. Students could learn what to do to put clients at the center.

Despite these contributions, however, the work of Binder, Bergman, and Price is problematic in its challenge to the constructed client. Drawing on the works of other critics, I will identify several ways in which their presentation of client-centeredness is flawed. ${ }^{26}$

First, through the development of an abstract, formal system for putting clients at the center of legal representation, Binder, Bergman, and Price do not effectively address differences among clients. ${ }^{27}$ The methods and techniques they propose for interviewing and counseling are relentlessly the same for each client. ${ }^{28}$ Although they mean to elicit the particularity of each client, they do not recognize that differences among clients might matter in

23. "In a client-centered world, . . . clients actively participate in identifying their problems, formulating potential solutions, and making decisions." Id. at 18.

24. See Dinerstein, supra note 13 , at 504.

25. For example, Binder, Bergman, and Price introduce their book by stating: "[This book] primarily explores the processes of interviewing and counseling. [It] attempts to provide a general approach to interviewing and counseling and an array of skills that you [the lawyer] can employ when talking to clients." BINDER ET AL., supra note 22, at 4.

26. See, e.g., Alfieri, supra note 19, at 14-19; Dinerstein, supra note 13; Robert D. Dinerstein, Clinical Texts and Contexts, 39 UCLA L. REv. 697 (1992); Stephen Ellmann, Lawyers and Clients, 34 UCLA L. Rev. 717 (1987); cf. William H. Simon, Homo Psychologicus: Notes on a New Legal Formalism, 32 STAN. L. REv. 487 (1980) (criticizing the psychological model of lawyer-client relationships).

27. See Alfieri, supra note 19, at 16; Dinerstein, Clinical Texts, supra note 26, at 706, 721-22.

28. The discussion of modification of the standard techniques, addressed principally in Chapter 14 on "Gathering Information from Atypical and Difficult Clients," is based on a model of the normal or standard client, for whom these techniques work, and the marginal, deviant client, for whom they do not. BINDER, ET AL., supra note 22, at 237-56. 
shaping those very methods and techniques. The implicit message is that their system works equally well for all clients, no matter what their race, gender, class, or age and no matter how their problem arose.

Second, although the method seeks to create a neutral background against which clients' stories and goals can be revealed, the method actually frames and shapes what clients will say and how clients make decisions. ${ }^{29}$ For example, in the information gathering stage of an interview, the lawyer elicits clients' stories based on a chronological sequence. ${ }^{30}$ But the chronological ordering of events is only one way to recount those events. Other methods of storytelling may focus on different aspects of the experience, may feel more familiar to the clients, or may produce different information. The problem with the method is not that framing and shaping occurs as the lawyer structures the interview-it could not be otherwise. The problem is not even that the choice of chronological ordering is necessarily the wrong one. Rather, Binder, Bergman, and Price pay no attention to the choice that the lawyer makes in the interviewing method, and they do not acknowledge the operation of power in the relationship when the lawyer alone frames the interview.

Another example reveals how the method affects the nature and scope of client decisionmaking. To help clients make decisions about a case, the lawyer asks the clients to identify economic, social, psychological, moral, political, and religious aspects of their concerns. ${ }^{31}$ Although clients are free to answer any way they wish, the categories themselves have effects on decision making. First, Binder, Bergman, and Price's brief definitions of these categories reflect a view that the meaning of each is clear and the categorization obvious. Actually, each of these categories has a complex set of cultural meanings. The decision about how to categorize any particular client's concern reflects multiple presuppositions about the categories, as well as about the concern itself. The lawyer may or may not share with the client a set of beliefs and understandings about the categories or the process of categorization. Within the Binder, Bergman, and Price method, because the lawyer establishes the categorical framework and assigns client concerns to their appropriate boxes, the lawyer's interpretation dominates.

Second, in this method of analyzing decisions, the lawyer effectively divides clients into categories of concerns, much like professors divide law into categories of doctrines. Although Binder, Bergman, and Price clients may not have their experiences completely reduced to the meanings created by legal doctrines, their experiences continue to be translated into the language of intellectual and professional disciplines. Thus, the lawyer using this method fosters an analysis of clients' experiences without much attention to the meaning or consequences for the client of the form chosen.

Third, Binder, Bergman, and Price have a rather rigid demarcation be-

29. See Alferi, supra note 19, at 19; Dinerstein, Clinical Texts, supra note 26, at 723-24.

30. BINDER ET AL., supra note 22, at 113-36.

31. Id. at 8-9, 201-03, 295. 
tween the legal world and the nonlegal world. ${ }^{32}$ As in the traditional constructions of clients within legal education, the authors confine the client to the nonlegal world. Although they do not accept the definition of clients based on legal concepts, Binder, Bergman, and Price structure their method around clients" "concerns" in the nonlegal world. They even assign prominence to the nonlegal world ${ }^{33}$ and identify clients as the experts of this realm. ${ }^{34}$ But the clients' world is strictly demarcated from the world of the law. Therefore, this model of client-centeredness provides no insight about the relationship between the two worlds. Lawyers must guard against the legal world overwhelming the nonlegal one and must assist clients when the two worlds present conflicts, but the dynamic between the two remains inscrutable. Other than increasing the emphasis on clients' nonlegal world, the model provides no meaningful basis for criticizing the legal world. The client may be at the center, but only of a limited and nonlegal realm.

This rigid division between the two worlds allows the lawyer to dominate the legal world. The lawyer is the expert when it comes to identifying and framing options, particularly options that are presented by the legal realm, ${ }^{35}$ and developing legal theories. ${ }^{36}$ For example, the lawyer conceives and develops alternative case theories that have a pivotal role in shaping client

32. Binder, Bergman, and Price write as if the legal world is completely separate from the nonlegal world:

[L]awyers' principal societal role is to help clients resolve problems, not merely to identify and apply legal rules. Nonetheless, too often lawyers conceive of clients' problems as though legal issues are at the problems' center, much as Ptolemy viewed the Solar System as though the Earth were at the center of the universe. But legal issues may be no more the essence of a client's problem than, perhaps, religion might be its essence if a troubled client chose to talk to a minister rather than to you, a lawyer. Whatever the legal aspects of a problem, nonlegal aspects frequently are at the heart of a client's concerns. Effective counseling inevitably requires that you elicit information about these nonlegal aspects and factor them into a problem's resolution.

Id. at 5; see also Paul R. Tremblay, On Persuasion and Paternalism: Lawyer Decisionmaking and the Questionably Competent Client, 1987 UTAH L. REv. 515, 529 n.65.

33. "[N]onlegal concerns often outweigh legal ones in a client's calculus of what solutions to adopt." BINDER ET AL., supra note 22, at 10. "The perhaps surprising filp side of this argument is that often a decision's probable legal consequences are not a client's primary concern." Id. at 13. "The prominence of nonlegal aspects of client problems affects our entire view of counseling, from initial interview through problem resolution. To help clients effectively resolve their problems, you must continually take account of, and help clients think through, nonlegal as well as legal dimensions." Id. at 14.

34. "[C]lients are likely to be able to predict nonlegal consequences far better than you [the lawyer] can." Id. at 261.

[Y]ou [the lawyer] almost always must ask clients what consequences they can foresee.

Your legal expertise is insufficient to allow you to predict all of the consequences specific to

a client's individual situation. For example, in counseling a client about whether to include an insurance-funded buyout provision in the buy-see terms of a partnership agreement, you usually will not know your client well enough to determine all the likely economic, social and psychological consequences that might follow from selecting such an arrangement.

Id. at 273; see also id. at 294-95. But see Dinerstein, Clinical Texts, supra note 26, at 705-06 (raising questions about the extent of Binder, Bergman, and Price's commitment to client expertise).

95.

35. See Dinerstein, supra note 13, at 589; see also BINDER ET AL., supra note 22, at 273, 294-

36. See BINDER ET AL., supra note 22, at 145. 
questioning and investigation strategy. ${ }^{37}$ The client does not collaborate, or even participate, in these tasks. ${ }^{38}$ This model differs from the traditional one in that the lawyer evaluates legal options to a significant degree according to their nonlegal consequences. The clients, however, participate in decisions only by injecting these nonlegal concerns. The theory excludes the clients and many of their judgments that could be understood as legal from the legal realm.

Finally, Binder, Bergman, and Price's model is inattentive to the dynamics of power within the lawyer-client relationship. Power appears to be inconsequential. The authors obscure the ways the lawyer may exercise power over clients or clients may resist the imposition of the lawyer's power. ${ }^{39}$ So long as the lawyer conforms to the method and applies the techniques properly, there is a presumption of power neutrality. 40 If the lawyer follows the model, then the clients supposedly cannot be subordinated. ${ }^{41}$ If the client is subordinated, then the lawyer is not applying the method correctly. The authors' model blocks sight of the complex negotiations between lawyer and client over the exercise of power in the relationship. ${ }^{42}$ Consequently, instead of dealing with issues of power, the book implicitly blames any power struggle or domination on an improper application of the model.43

In addition, the model does not consider the social power that different clients bring to the relationship. ${ }^{44}$ Therefore, Binder, Bergman, and Price treat all client decisionmaking the same no matter the clients' social back-

37. Id. at 146-64.

38. Binder, Bergman, and Price analogize the client to a patron at a restaurant and the lawyer's work to the food preparation:

In many of the best restaurants, customers see only the food that is served, not the helter-skelter of kitchen activity that goes into its preparation. The thoughts in this chapter ["Theory Development: Developing Potential Evidence"] are the equivalent of the kitchen activities in restaurants. Converting theories to elements, recasting elements to factual terms, and identifying potential evidence are thought processes that go on out of sight of clients. Clients will be aware only of the questions you ask. But just as the way that the food is served affects a diner's enjoyment of it, so does the way you question affect the information you receive.

Id. at $163-64$.

39. See Sarat, supra note 2, at 43-44.

40. BINDER ET AL., supra note 22, at 288-89, 325-26.

41. But see Ellmann, supra note 26 (identifying the possibilities for lawyer manipulation of clients within the model).

42. For an analysis of lawyer-client interaction that is attentive to the dynamics of power in divorce disputes, see Austin Sarat \& William L.F. Felstiner, Law and Strategy in the Divorce Lawyer's Office, 20 LAW \& Soc'x REv. 93 (1986).

43. When discussing power in the lawyer-client relationship, Binder, Bergman, and Price simply state: "Awareness of how you [the lawyer] may inadvertently influence clients need not make you paranoid about every word you utter. Rather, understanding that absolute neutrality is probably impossible may underlie the importance of following a generally client-centered approach. Such an approach can minimize, if not eliminate, your infuence." BINDER ET AL., supra note 22, at 326. For additional critiques of the book's inattention to the dynamics of power between the lavryer and client, see Alfieri, supra note 19, at 19 (discussing power in Binder, Bergman, and Price's concept of the lawyer-client relationship in terms of interpretive privilege); Dinerstein, Clinical Texts, supra note 26, at 722 (noting inattention to lawyer dominance over clients).

44. Cf. Simon, supra note 26, at 523 (criticizing the psychological model for not addressing power differentials within the lawyer-client relationship). 
ground or situation. For example, a poor, single mother using a weak but viable legal claim to fight an eviction from a tiny apartment should elicit the same response from a lawyer as an executive of a pharmaceutical company who wants to exploit arguable ambiguities in environmental legislation to dispose of toxic waste in a marginally safe manner. In each case, the lawyer would present all of the alternatives based on legal analysis and then elicit the client's alternatives derived from nonlegal knowledge. Next the lawyer and client would predict legal and nonlegal consequences of the options, exercising their appropriate expertise in their respective realms. ${ }^{45}$ In deciding on a course of action, the lawyer might address any of the client's moral concerns. ${ }^{46}$ The lawyer might even talk with the client about the lawyer's own moral concerns. ${ }^{47}$

There are at least two problems with this approach. First, in terms of the method, the lawyer treats all cases the same whether the client is a poor, single mother or a pharmaceutical executive. There is no sense that these situations pose different issues for the lawyer. The model neglects to recognize the importance of the context of each case in the decisionmaking process. ${ }^{48}$ The relationship of each client's weak legal claims to their respective positions in the world is not addressed. Therefore, the decisionmaking model disguises the relationship of the client's situation in the social world to both the client's legal choices and the lawyer's stance toward those choices. In this further separation of the world of law from the social world, Binder, Bergman, and Price mask again the connections between the two. Second, issues of power are reduced to personal moral concerns. Instead of considering the nature of the client's social power and the significance of that social power within the operation of the legal system, the model deals with this power solely in terms of idiosyncratic personal moral "concerns."

Binder, Bergman, and Price have not successfully destabilized the constructed client of legal education. Rather they have partially reconfigured the clients' world and given clients a new identity within it. Clients are no longer defined primarily by reference to legal criteria established by the court. The method of lawyering now serves to define clients. Within that method, the lawyer circumscribes clients' abilities to give meaning to their own experiences and reshape the legal world by both separating personal concerns from legal issues and by constructing the enhanced domain of the personal according to the categories of professional disciplines. Although Binder, Bergman, and Price think of themselves as giving clients greater control over the definition of their interests and motivations within the personal realm, their methods use the lawyer-client relationship to construct the interests and motivations of clients through criteria the law controls. Furthermore, as with the old constructed clients, these new constructed clients continue to provide for the legal system motivations seen as external to and

45. BINDER ET AL., supra note 22, at 292-95.

46. Id. at 279-80, 347-49.

47. Id. at 279-80, 282-84, 349-50, 358-59.

48. See Dinerstein, Clinical Texts, supra note 26, at 721, 724-25. 
shaped without reference to the legal world. Once again, the legal system is viewed as merely implementing an end ascribed to the client. By never addressing the relationship of these ascribed motivations to the operation of the legal system, the authors minimize the possibilities of a critique of that system. Although client-centeredness does not successfully dislodge the constructed client of legal education, it has spawned, through its greater attention to clients, renewed attempts at destabilizing the entrenched figure.

\section{New Directions}

There is a growing body of work that attempts to unite theory and practice in law. It is sometimes identified as clinical legal theory, a theory of practice, or the theoretics of practice. ${ }^{49}$ This diverse literature refocuses legal thought on clients who are disempowered. In this respect, it recaptures the drive for a contextualized understanding of clients that has animated the creation and development of live-client clinics. It also renews the search for a self-critical understanding of the meaning of legal work with clients, and it develops forms of practice that reflect such an understanding. ${ }^{50}$ Through several themes, this emerging literature takes up the challenges to the constructed client that prevail in legal thought and legal action.

First, theory of practice scholarship takes care to situate clients within the social world, taking into account the particularities of the clients' experiences and circumstances. It rigorously demands attention to the details of the clients' world and a constant skepticism about abstraction and generalization. Gerald López, perhaps more than any other writer in this developing tradition, has both argued for the critical importance of understanding the concrete details of clients' situations ${ }^{51}$ and integrated this understanding into complex descriptions of law practice and legal work. ${ }^{52}$ In contrasting two conceptions of lawyering, regnant and rebellious, López has placed clients at the center of a multifaceted vision of the legal world, created through the concrete practices of rebellious lawyering. Clients are at the center not as abstract, autonomous individuals, with bare motivations, but rather as complex beings enmeshed in all aspects of their lives and in relationship with lawyers. Lawyers who participate in rebellious lawyering must be committed to the often difficult and painstaking work of learning the details of cli-

49. See, e.g., Anthony V. Alfieri, Reconstructive Poverty Law Practice: Learning Lessons of Client Narrative, 100 YALE L.J. 2107 (1991); Phyllis Goldfarb, $A$ Theory-Practice Spiral: The Ethics of Feminism and Clinical Education, 75 MiNN. L. REv. 1599 (1991); Symposium, The Emperor's Old Prose: Reexamining the Language of Law, 77 CORNELL L. REv. 1233 (1992); Symposium, Theoretics of Practice: The Integration of Progressive Thought and Action, 43 HASTINGS L.J. 717 (1992).

50. See Gerald P. López, Rebellious LaWyering: ONe Chicano's Vision of ProgresSIVE LAW Practice (1992); Foreword to Symposium, Theoretics of Practice: The Integration of Progressive Thought and Action, supra note 49, at xvii.

51. López, supra note 3, at 336, 343-57; Gerald P. López, The Work We Know So Little About, 42 STAN. L. REV. 1, 11 (1989).

52. LÓPEZ, supra note 50; Gerald P. López, Reconceiving Civil Rights Practice: Seven Weeks in the Life of a Rebellious Collaboration, 77 GEo. L.J. 1603 (1989); López, The Work We Know So Little About, supra note 51, at 9-10. 
ents' experiences in the clients' own terms. ${ }^{53}$ Even for lawyers who do not embrace rebellious lawyering, López has shown how situating clients within the details of their worlds is critical to effective legal action. ${ }^{54}$

Second, while recognizing the importance of seeking out and describing the details of clients' lives, this work explicitly acknowledges the partiality and uncertainty of all accounts of clients and their world. Descriptions of the particular character of the clients' situations refiect multiple, shifting perspectives, each of which is itself situated. Lawyers and clients produce these descriptions, not through their isolated reflection, but as part of and in response to their evolving relationships with each other and with other participants in a case. Lucie White, in her descriptions of legal work, has emphasized the tentativeness of the process of understanding clients' lives and the need for patience in undertaking that process. ${ }^{55}$ For example, White presents her description of Mrs. G., a client of hers while a legal services attorney in North Carolina, not as a completed portrait of Mrs. G., but as a moment in an ongoing, self-critical process of description. ${ }^{56}$ Although the process of description- of Mrs. G., of herself, of the relationship between lawyer and client, of the welfare institutions within which Mrs. G.'s case arises and legal action is taken-is essential to White's analysis, she recognizes the partiality of her account and her critique, as well as the inevitable ambiguities and uncertainties that arise in understanding the events she describes. ${ }^{57}$

Third, the theoretics of practice literature challenges the demarcations between the legal and social worlds that characterize much of current legal thought. It accepts no fixed and stable relationship between the two, but rather sees a complex and shifting relationship that itself must be understood within the parameters of each particular situation. These divisions, which themselves serve to give content to each world, are key to creating the identity of the client, who has a particular existence in each of those worlds. In creating vastly different spaces for clients in the legal world, the theoretics of practice work shifts the boundary between the legal and the nonlegal. For example, for López, the details of clients' lives and situations are important, not just as aspects of personal characteristics or traits, but as essential elements in defining legal problems, identifying and creating legal solutions, and making legal decisions. ${ }^{58} \mathrm{He}$ defines the world of the law that these clients populate as one characterized by "The Practice of Using Stories to Solve Problems."59 In addition, the relationship between lawyer and client is not built across separate spheres-legal and nonlegal—but within a single sphere of overlapping practices. When López's rebellious lawyers embrace a

53. LÓPEZ, supra note 50 , at 11-82.

54. López, supra note 3 , at 345-52.

55. Lucie White, Paradox, Piece-Work, and Patience, 43 HASTINGS L.J. 853, 854-55 (1992).

56. Lucie E. White, Subordination, Rhetorical Survival Skills, and Sunday Shoes: Notes on the Hearing of Mrs, G., 38 BUFF. L. REV. 1 (1990).

57. Id. at 51-52.

58. LOPEZ, supra note 50, at 38-41.

59. Id. at 39. 
practice of working with and not for their clients, they are accepting the clients' knowledge and experience as an integral part of legal thought and action. ${ }^{60}$

Fourth, this scholarship of theory and practice pays close attention to the dynamics of power in relationships within the legal system. The work examines how power is deployed as part of the routine interactions of people within that system-between lawyers, clients, judges, clerks, and bureaucrats. Austin Sarat and William Felstiner, in their detailed, observational study of divorce practice, did pioneering work identifying the operation of power within the lawyer-client relationship. 61 Within that relationship, they found that lawyers and clients engage in a complex negotiation involving "different agendas, expectations, and senses of justice."62 Power in that negotiation, according to Sarat and Felstiner, is "mobile and volatile, ... it circulates such that both lawyer and client can be considered more or less powerful, even at the same time."63 Because power is exercised within the "space of law," the privilege that the lawyer has and the familiarity that the lawyer feels create advantages in the negotiation. ${ }^{64}$ The lawyer does not impose power in a direct or mechanical way. Rather, within the interaction of lawyer and client, there is "resistance as well as acquiescence, contest as well as cooperation, suspicion as well as commitment."65 Others, such as Anthony Alfieri, have critically examined power within the lawyer-client relationship in the context of poverty law practice. ${ }^{66}$

Extending the analysis of the dynamics of power beyond the individual relationships formed within the legal system, other scholars have focused on the concealed forms of power within institutions. They have examined how the everyday interactions within the routines of those institutions create and maintain institutional power and also how those institutions in turn channel the flow of power towards some and not others, thereby shaping the exercise of power within relationships. For example, Lucie White, in her study of Mrs. G., described the complex workings of power in Mrs. G.'s contacts with the welfare system. She identified both the characteristics of the exercise of institutional power-intimidation, humiliation, and objectificationthat create the systemic injustice that Mrs. G. confronts, as well as Mrs. G.'s evasive maneuvers to challenge and to survive within the welfare system. ${ }^{67}$ As White emphasizes throughout her work, it is not enough to see the ways that the routines that people participate in create institutional power; it is

60. Id. at 43-56.

61. Sarat \& Felstiner, supra note 42.

62. Id. at 125 .

63. William L.F. Felstiner \& Austin Sarat, Enactments of Power: Negotiating Reality and Responsibility in Lawyer-Client Interactions, 77 CORNELL L. REv. 1447, 1450 (1992).

64. Id. at 1457-58.

65. Id. at 1450; see also L6́PEZ, supra note 50, at 41-43 (describing power in terms of problemsolving stories).

66. Alfieri, supra note 49; see also Christopher P. Gilkerson, Poverty Law Narratives: The Critical Practice and Theory of Receiving and Translating Client Stories, 43 HASTINGs L.J. 861 (1992).

67. White, supra note 56 , at 32-52. 
necessary also to be aware of how the "institutional matrices" created by these routines shape and constrain future interactions. ${ }^{68}$

In its quest to make sense of the particularities of the client's situation while also recognizing the partiality of those accounts, in its search for new kinds of legal practice that challenge the boundaries between the legal and the nonlegal and that carefully attend to the workings of power, this literature of theory and practice draws upon diverse methodologies. These methodologies seek to describe a client's world while maintaining a self-critical understanding of how the description itself is shaped by language and cultural meaning. Listening to and describing clients in a way that does not impose upon them categories constructed by lawyers is a complex and diffcult task that demands creativity and perseverance. ${ }^{69}$ In their beginning efforts to realize this task, scholars have used narratives of many sorts, telling their own or other people's stories or imagining stories often drawn from their own experiences. They have transcribed dialogues and imagined conversation. They have borrowed from the methodologies of ethnography and phenomenology. They have recognized that a theory of practice cannot be expressed solely through articles and books, but must be articulated as a part of the practice itself. ${ }^{70}$

Although the theoretics of practice literature is fundamentally concerned with subordinated clients, it provides a vantage point for understanding other clients and other aspects of the law and the legal system. As this work attacks conceptions of disempowered clients that tend to dominate poverty law practice, it also has potential to shatter the constructed client of legal education. For example, understanding how poor clients are situated in the social world alerts us to the importance of doing the same for all clients, whether individuals or groups. Experience with partial and tentative description makes us wary of descriptions that claim to be universal or neutral. As the line between legal and nonlegal worlds in the lives of indigent clients dissolves, we can see more clearly how the drawing of that line itself functions in particular situations to the advantage of some and the disadvantage of others. Examining the dynamics of power within the relationships and institutions of the legal system reveals the experience of the powerful as well as the disempowered. The clients who are present in this work pose a threat to the generalized, abstract clients of traditional legal education who provide bare motivations formed outside the parameters of the legal system.

The threat, however, is only a possibility. Several barriers remain before the constructed client of legal education can be displaced. First, the work of understanding clients and of developing new forms of practice must be central to legal education. That work cannot go on without clients being a part of the law school. Although the first significant attack on the constructed

68. Lucie E. White, Seeking "... The Faces of Otherness... ." A Response to Professors Sarat, Felstiner, and Cahn, 77 CORNELL L. REV. 1499, 1505-06 (1992).

69. See LOPEZ, supra note 50, at 47-62; White, supra note 68, at 1508.

70. See, e.g., Alfieri, supra note 49; Gilkerson, supra note 66; Symposium, The Emperor's Old Prose, supra note 49. 
client, the creation of live-client clinics, proved to be an insufficient step in dislodging the entrenched, yet shadowy classroom figure, those clinics remain an absolutely essential element of an alternative educational practice that could fulfill the aspirations of the theoretics of practice literature. For students to learn the importance of people's lives, they must have opportunities to develop that knowledge as a fundamental part of their legal education. To allow that learning to be peripheral or haphazard is to permit the constructed clients to continue their domination of the law school.

Furthermore, doing legal practice as a part of the law school contributes to making the understanding of clients' lives and the development of new forms of practice an important part of legal discourse. Attention to clients and practice must continue. Integrating this work into the life of the law school helps to make the law school a site for expanding and transforming our understanding of what constitutes legal thought and legal practice. That integration could challenge many assumptions that currently dominate law schools about what legal theory is and how it is done. ${ }^{71}$

The routines of educational method pose a related barrier. To a large extent, the literature of theory and practice has not addressed educational methodology. ${ }^{72}$ To a great extent, even those receptive to the theoretics of practice literature find it difficult to change their classroom practices. Students take with them the implicit visions of clients that they get from the routine practices of law school. Therefore, throughout legal education, both in the classroom and the clinic, the insights of the scholarship of theory and practice must be expressed in different educational practices. As with the constructed client of legal education, the client who takes shape in these alternative practices will embody the most fundamental assumptions of this new legal thought. A self-conscious, critical educational methodology, however, remains an as yet unrealized element of a theoretics of practice.

\section{CONSEquences of the Constructed Client for the Discourse of Civic Values}

Understanding the dominant construction of clients and the challenges to this construct provides insight into recent efforts to draw upon the idea of civic republicanism to transform legal thought and legal education, of which this symposium is a part. The possibilities for meaningful change in legal thought resulting from discourse about civic values are limited in scope and meaning if the legal profession and the law schools continue with the constructed client. ${ }^{73}$ If the legal discourse regarding civic values in the law assumes only the same client constructed within legal education, then it will replicate the existing dialogue of legal education. In reconceptualizing the relationship between individuality and community in the law, the discourse

71. See White, supra note 55 , at 854-55.

72. For exceptions, see López, supra note 3; Shalleck, supra note 19.

73. Cf. Schlag, supra note 1, at $1659-60$ (discussing the problem of the subject generally in republican theories of adjudication). 
about civic virtue needs to reclaim clients as they are situated in the world to make them part of the dialogue of the law. To a great extent, the current literature of civic virtue and republicanism relies upon the dominant construction of the client. Judges are entreated to engage in civic discourse; legal institutions are reinterpreted in terms of civic values; and lawyers are encouraged to rethink their obligations to a republican community, discussing their concerns about the community with their clients. The dialogue, however, does not see clients as the source or site of a different understanding of community in law. At most they are the object of civic education, not crucial participants in building an understanding of what civic virtue means in the law. Discussion about civic virtue cannot change legal discourse if clients continue to be used to supply somewhat different motivations that prefigure the ends of this altered legal thought. Within the language of civic discourse, clients are citizens who come in contact with the law in ways that cause them to seek lawyers. It is critical that their experience shape the discussion.

Furthermore, the law, legal institutions, and lawyers would need to change fundamentally in order to include clients' experiences in a meaningful dialogue about civic values. Civic discourse, to realize its own aspirations, needs to be truly situated within the complex, multidimensional communities of our society. ${ }^{74}$ Otherwise it becomes an instrument that creates a false sense of community-an exclusive community. The works of those attempting to challenge the constructed client through a scholarship of theory and practice can alert us to the limitations and possibilities of civic discourse. The rigorous demand for detailed descriptions of the particular situations of clients, the sensitivity to the partiality of those accounts, the recognition of the fluid boundary between the legal and social worlds, the careful attention to the dynamics of power, and the concern with the development of self-critical methodologies caution us about the difficulty and fragility of an inclusive civic dialogue. These same themes also suggest the transformative and exciting possibilities of a reconceptualized civic dialogue rooted in a new form of practice that truly incorporates clients. 